\title{
SEMANTIC STUDY OF AL-HARB WORDS IN THE QUR'AN ACCORDING TO THE AZ-ZUHAILI WAHBAH
}

\author{
Ahmad Ridla Syahida \\ Pascasarjana UIN Sunan Gunung Djati Bandung \\ Email : ridlaridla@gmail.com
}

\begin{abstract}
This research is a semantic study that aims to uncover the underlying meanings and relational meanings of the word al-qitāl and al-harb contained in the Koran. Lafadz al-qitāl and its derivation are repeated 65 times, while the phrase al-harb and their origin are only repeated nine times. With this semantic approach to the word, it is expected to be able to provide a deeper understanding and provide a world view of the Koran. This study also aims to find out how the sources, methods, and interpretations of Wahbah AzZuhaili are interpreted in Al-Munir so that they can find out and explore the various characteristics of their understanding of the words al-qital and al-harb in that interpretation. The method used in this research is a descriptive-analysis method to describe and analyze data. The type of data used in this study is qualitative. In contrast, the primary data source used in this study is Al-Munir's interpretation supported by other sources relevant to the object of this study. The results of this study indicate that in terms of the origin of understanding Wahbah Az-Zuhaili tries to combine the interpretation of bil ma'tsur and the interpretation of bil ma'qul (ar-ra'yi), with the style of language and contemporary approaches Wahbah Az-Zuhaili works to present a solutive analysis and under the conditions of the times.
\end{abstract}

Keywords: Al-Harb, Al-Quran, Az-Zuhaili

\section{INTRODUCTION}

The Koran for Muslims is kalāmullah, which was revealed to the Prophet Muhammad through the mediation of Jibril for approximately twenty-three years (Az-Zarqāni, 2010). This holy book has extraordinary power that is beyond any ability, as the word of Allah in Q.S. Al-Hasyr [59]: 21.

The contents of the divine message delivered by the Prophet at the beginning of the 7th century laid the foundation in regulating the social system both concerning the problems of the individual and social life of Muslims in various aspects. The Muslim community began its existence and gained life force by responding to the preaching of the Qur'an. That is why the Qur'an is right at the heart of Muslim beliefs and various religious experiences.

Al-Qur'an, with the teachings contained in it, not only doctrines its adherents in terms of 'ulubid directly to Allah, but the teachings of the Qur'an break down various dimensions of life, reconstructing different existing ideologies and passed down from generation to generation. The Qur'an not only commands Muslims to worship Allah by establishing prayers, fasting, reciting prayers, reciting prayer beads at day and night. But more than that, al-Qur'an teaches its adherents to an extreme doctrine about the concept of maintaining the glory of religion, namely al-qitāl (war), where this term is used as a unifying soul in fighting for the integrity of Islam.

In accordance with the spirit of Islamic teachings, everything is directed towards peace and coexistence between humans and others. In all situations, dialogue must be prioritized in order to create reconciliation between various conflicting parties (Makhmudah, 2015). This is where the spirit of peace becomes the primary goal of the Islamic religion in order to create a conducive and harmonious

* Copyright (c) 2019 Ahmad Ridla Syahida

This work is licensed under a Creative Commons Attribution-ShareAlike 4.0 International License.

Received: 29 May 2019; Revised: 10 Juny 2019; Accepted: 25 Juny 2019 
IJIK, Vol. 9 No. 2: 61-71

Semantic Study Of Al-Harb Words In The Qur'an According To The Az-Zuhaili Wahbah Ahmad Ridla Syahida

environment, avoiding all forms of division and chaos with various interests. In this case, the Koran expressly states the attitude towards war, that is the effort to prevent it and is not carried out except after all the means of peace have been taken (Shihab, 1996).

The history of the descent of the verses of the Qur'an proves that the Messenger of Allah had been ordered to wage jihad since he was in Mecca, and long before the permission to take up arms to defend himself and religion. But the first battle in Islamic history took place in the second year of the Hijri, precisely 17 Ramadan with the outbreak of the Badr War (Shihab, 1996), that is after descending verses that allow war to take up arms. As in Q.S Al-Hajj [22]: 39-40.

If seen more broadly, there is a difference between the understanding of jihad in language and its use in the Koran, even the word jihad in much of the Islamic Fiqh literature is narrowed in meaning to be a war against infidels, also according to some jurisprudents including the war against dissidents/rebel (alBughat). The purpose of jihad with war (al-Qitāl) in some fiqh literature is what leads some people, who are popularly called 'jihadists' groups, to say that shar'ar jihad has no other meaning except war in the way of Allah (Hanafi, 2013).

In this view, people outside of Islam are enemies of Islam, because they are infidels, so the relationship between Muslims and them is built on the basis of war even though the two words (jihād and qitāl) have very fundamental differences, not only in language but also in substance and content.

Al-Qitāl comes from the root word qatala, which has the underlying meaning of subjecting and taking the lives of others (Fâris \& Faris, 2013). In comparison, jihad is taken from the word jahd, which means tired/difficult. Ibn Faris in the Mu'jam Maqāyīs Al-Lughah explains that all names consisting of the letter j-h-d originally had the meaning of difficulty or difficulty and were similar to them (Fâris \& Faris, 2013). Thus, jihad means a sincere attempt by a Muslim in fighting devil and evil, starting from the soul due to the whisperings and temptations of Satan, to the efforts to eradicate crime and evil in society (Hanafi, 2013).

The views of some fuqaha, especially from the mutaakhirin circles which give the meaning of syar'i jihad are identical to the war on the path of God, can be understood because in their view war is the highest level of jihad. However, these two words actually have fundamental differences because the scope of jihad is broader than just fighting in the way of Allah. Every Muslim is obliged to do jihad with soul, or property, or oral, or heart. The faith of a new Muslim will reach the level of perfection by carrying out jihad in his life (Hanafi, 2013).

Jihad is not synonymous with war, whatever the background that triggers and becomes the purpose of the war. Jihad is a war that is fought in the way of Allah (fi sabilillāh) only and is only allowed in certain situations. Therefore it can be categorized that jihad is a 'spirit' rather than an operational field of war itself. If the war goes out of the corridor of 'in the way of Allah', then when it is no longer called jihad but has turned into a lousy deed which is not justified by the Shari'a and Islamic ethics it can even be categorized as a form of crimes against humanity (Sariningsih, Yuniyanto, \& Isawati, 2019).

Therefore, it is not allowed to attack someone because of different religions or infidels. Because the war in Islam primarily aims to maintain the freedom of preaching rather than preaching. Because preaching Islam to non-Muslims through violence is prohibited in the Qur'an (Q.S Al-Baqarah [2]: 256). If Islam were spread with swords, surely it would be lost from the hearts of its followers along with the loss of Islamic power. But the purpose of the war is to maintain the creed, secure the freedom of da'wah, and ward off attacks from outside Q.S Al-Baqarah [2]: 190.

From here, it is very wrong the view of the western intellectuals who declare "glorious Islam on the sword," "Islam spread by the war." History proves the opposite. In many parts of the world, as in Malay 
IJIK, Vol. 9 No. 2: 61-71

Semantic Study Of Al-Harb Words In The Qur'an According To The Az-Zuhaili Wahbah Ahmad Ridla Syahida

soil, Islam is spread by peaceful means. This is what makes other Western thinkers like Thomas Carlel, Gustav Le Bon, a famous historian from France, criticize the thesis of his colleagues by denying the argument of Islam is spread with the sword. Especially if we understand the permission for warfare only to be obtained from God after 15 years, the Prophet Muhammad developed Islamic da'wah (Hanafi, 2013).

Seeing the understanding of the term 'war' is so essential for every Muslim so that Muslims avoid the anarchist and radical attitude based on religion. Then it becomes a necessity to explore the meaning of the words used by the Koran in describing the purpose of war in more depth. Because if you pay attention today, there is a phenomenon in some Muslims who misunderstood the use and meaning of these terms in Islam, more specifically the words al-qitāl and al-harb contained in the al-Qur'an (Hanafi, 2013).

The Koran in describing the term "war" uses at least four words, namely the word; an-nafr, al-jihad, al-qital and al-harb (Junaidy, 2018), but of the four terms, only two diction which is considered in the underlying meaning indicates the meaning of the first war: al-Qital and second: al-Harb. But from both of them, only the word al-Qitāl is widely used by the Koran in various verses and letters in expressing forms of physical contact resistance both offensively (jihād ad-dafi) and defensive (jihād ath-thalab) when dealing with enemies (war) (Al-Ja'wani, 1983).

Although relational in some places the Koran uses the word jihad to show physical confrontation (war) activities such as the word of Allah Almighty (QS At-Taubah [9]: 41) Regarding this verse Wahbah Az-Zuhaili commented that what is meant by jihad in the context of this verse is physical war (al-Qital) against the enemy (Az-Zuhaili, 1998). However, in the underlying meaning in several places in the Koran, the word jihad does not merely contain ideology to exert all abilities so that physical confrontation (war) occurs, but the meaning of jihad holds a broader meaning than that.

Although the word jihad has been used in verses that were revealed before the Prophet emigrated (Makkiyyah), but the scholars agreed to declare that the obligation to fight only came down in the second year of Hijrah, namely the descent of Q.S Al-Hajj [22]: 39-40. One of the agreed verses descended on the Makkiyyah period which spoke of jihad, namely the preamble (Q.S Al-Ankabut [29]: 6)

The word jihad referred to in that verse is not fighting - in the path of Allah - against the enemy physically, but meaningful jihad in the form of jihad against lust and devils, also bearing the burden of suffering by being patient (Hanafi, 2013). In this study, the author only limits in analyzing one term that is considered to have a fundamental meaning containing the meaning of war, namely lafadz: al-Harb. Seeing that there has been no discussion of this research, especially the discussion by using a semantic approach to the words al-Qital and al-Harb, the writer tries to conduct a study and analysis in order to be able to comprehend comprehensively and in-depth meaning of the phrase al-Qital and Al-Harb in the Koran. The reason the author chose the interpretation of Al-Munīr fī Al-'Aqīdah wa Asy-Syarīah wa Al-Manhaj by Wahbah Az-Zuhaili as the object of research, which includes seeing that Wahbah Az-Zuhaili was a mufassir who lived in the century -20, indeed considered more able to read the conditions and challenges today, apart from the ability/capability of Wahbah Az-Zuhaili as a professor and expert in the field of law certainly gives its own color in understanding the concept of war in accordance with Islamic law and based on the present context.

In his commentary as well, Wahbah Az-Zuhaili elaborates the words al-Qitāl and al-Harb broadly and deeply, supported by the approach/style of adaby itjimā'i, which is one of the characteristics expected to be able to provide different perspectives and colors in reconstructing understanding of the concept the war is fought now. 
IJIK, Vol. 9 No. 2: 61-71

Semantic Study Of Al-Harb Words In The Qur'an According To The Az-Zuhaili Wahbah

Ahmad Ridla Syahida

In accordance with this background, the authors hope that by examining al-Harb's interpretation through the semantic approach, it is expected to be able to provide a new paradigm; in understanding and using the term, both for Muslims correctly and for the entire Indonesian community at large.

\section{RESEARCH METHOD}

The method used by the authors in this research is a descriptive-analysis method, with the following characteristics (1) focusing on solving problems that exist today with descriptive techniques, namely research, analysis, and classification. (2) the data collected is first arranged, explained, and then analyzed. Therefore, this method is often called the descriptive-analysis method (Sugiyono, 2011)

\section{RESULT AND DISCUSSION}

\section{Semantic Analysis of the Word Al-Harb and Its Interpretation}

\section{The Basic Meaning of the Word Al-Harb}

As the author has said in the previous discussion, that the use of the word al-harb in the Qur'an is different from the use of the phrase al-qitāl, the use of phrase al-harb is very little or even arguably rarely used by the Qur'an in interpreting the word war.

As for the further study, the reasons why the word al-harb in the Qur'an is not as much as the use of the words jihad and qital (Rodin, 2016), as stated by Muhammad Ibn Nashir Ibn' Abdurrahman AlJa'wani in his book entitled Al-Qitāl Fi Al-Islam Ahkamuhu Wa Tasyri'atuhu. He explained that the word al-harb was synonymous with warfare caused by the burning of emotions between figures (individuals), groups, and communities whose goal was individual. Whereas the words jihad and qital are quranic expressions (have a profound impact). Therefore harb can be identified as a war of people for the sake of personal image and the honor of a group/people with the aim of seeking profit, not on the basis of exalting the religion of Allah (Al-Ja'wani, 1983). Perhaps that is one of the reasons why the word al-harb is used by the Qur'an a little in expressing the word war.

From the results of the search for the word al-harb, no derivation and various musytak (original words) found word al-harb, other than the word الْمحْرَابَ يُحَارِبُونَ. This is very much different from what happened to lafadz al-qitāl whose word usage is very diverse. From the results of observations of word الْحَرْبُ and its derivation in the Qur'an, the author found this word repeated nine times.

If explored further, morphologically the word al-harb is a mass isim of fiulat tsulatsi mujarrad said

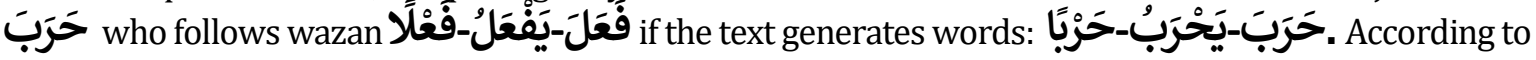
Ar-Raghib Al-Ashfahani in his book Mufradat Al-Fadz Al-Qur'an, the basic meaning of the word al-harb is taken from the fi'il madhi which is 'ain' fi'il with fathah (haraba) meaning to rob. Furthermore, Muhammad Murtadha Al-Husain Az-Zabidi, in his dictionary Taj Al-rusurus added that the word al-harb is the opposite of peace and tranquility. As is well known that what is meant by this word is war (الْقِتَالُ), then As-Suhaili asserted that what is meant by al-harb is to attack each other by throwing arrows and then clashing swords with each other, then wrestling (physical contact without using any tools) when war conditions are raging, or various circumstances that describe war condition.

But if the word al-harb is taken from the fi'il madhi which is 'ain' the fi'il with the kasrah (hariba)

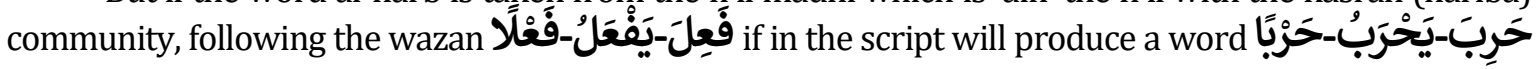


IJIK, Vol. 9 No. 2: 61-71

Semantic Study Of Al-Harb Words In The Qur'an According To The Az-Zuhaili Wahbah

Ahmad Ridla Syahida

, then the word when used for example like حَرِبَ الَّرجُجل meaningful إشْتَدَّ غَضَبْبُ which means to be very angry.

Perhaps only the word al-harb, which is both lexical (dictionary) or grammatical, shows the meaning of war explicitly. Which is linguistically, basically, the word al-harb is well-known and wellknown among the Arabs, which implies insecurity and security, which is contextually understood as war. Because the so-called war is certainly landed there unusual noise, unstable conditions, and chaos. So that in its development in religious terms there is what is called دَارَ الحَرْبِ or referred to as the area of the polytheists where there is no agreement/peace between the two. And the specialty of this word, in terms of religion does not recognize the existence of دَار الِْقتَّالُ this indicates the language of the word al-harb historically is far more rooted in terms of meaning than the phrase al-qitāl in showing the purpose of war.

Then the word formed from word al-harb is the word الِْمْحَرَابَ which at first the writer experienced confusion to determine whether the word has the same field of meaning as al-harb or not.

The in the Qur'an is repeated 4 times, which is found in Surah Q. Ali Imran: 37 and 37. The verse belongs to the madaniyyah group. And 2 verses are included in the group makkiyyah, namely (Q.S Mariyam: 11) and (Q.S Shad: 21).

After further investigation, the word الْمِحْرَابَ in the Qur'an translation of the official version of the Department of Religion, this word is only interpreted as mihrab, a place of prayer, mosque, or place of worship mariyam dibaitul maqdis, the meaning exclusively relies on the meaning of the translation of the Qur'an ' an Indonesian Ministry of Religion.

Here are the verses that contain the word mihrab: (QS Ali Imran [3]: 37), (QS Ali Imran [3]: 39), (QS Shad [38]: 21) and (Q.S. Maryam [19]: 11)

Semantically, it turns out the word الْمِحْرَابَ has a strong bond of meaning with the root word,

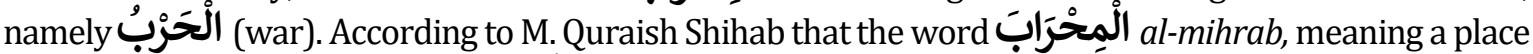
to throw, is derived from the word حِرَبْ hirab, a kind of javelin (tool of war). This word develops its meaning so that it is also understood in the sense of the place of prayer or a room / special place again used as a high place to fight lust and devil. Facing a sincere face to God is like fighting against an enemy (shaitan) so that the place faces is called mihrab. In a further development, the word mihrab is used in the sense of the place where the imam stands to lead the prayer (Wartini, 2014).

\section{The Relational Meaning of the Word Al-Harb}

\section{The Relational Meaning of the Word Al-Harb}

In tendency, the word al-harb is more influential in giving meaning to war than other words. This indication can be seen from the rare use of the word al-harb compared to separate words. As if the word al-harb has motives, aims, and means that are different from other words in describing the conditions of war.

In this case Al-Fauruzabadi in his book Bashair Dzawi At-Tamyiz Fi Lathaif Al-Kitab Al-Aziz, there are at least two meanings of the word al-harb which stands alone as follows:

1. Meaning Infidelity/mistake

As the word of Allah Almighty: (Q.S Muhammad [47]:4)

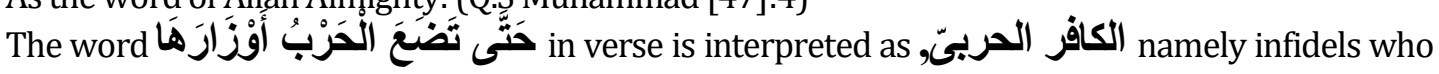

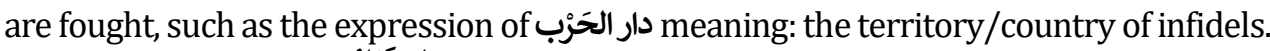

2. $\quad$ Meaning of war (القِقَّالْ)

As the word of Allah Almighty: (Q.S Al-Anfal [8]: 57) and (Q.S Al-Maidah [5]: 64) 
IJIK, Vol. 9 No. 2: 61-71

Semantic Study Of Al-Harb Words In The Qur'an According To The Az-Zuhaili Wahbah

Ahmad Ridla Syahida

In both verses, the word الْحَرْبُ interpreted as war (القِتَّالُ).

\section{The Relational Meaning of Al-Harb's Words whose Calls (Calls to War) Come from Allah and His Messenger}

Verses that speak in this context when seen only in one verse only, namely in (Q.S. Al-Baqarah [2]: 279):

This type of verse is almost the same as what is in the QS At-Taubah [9]: 30 and Al-Munafiqun [63]: 4 , both of these types equally attribute the "cry" of war from God even though grammatically and from the level of syntax there is a fundamental difference. In this verse, the word al-harb is interpreted as Allah's opposition to His creatures which are not only understood as an essential war, or المخالفة.

The verse speaks in the context of resistance against those who practice usury. If interpreted further: if you do not carry out what is ordered so that you collect the rest of usury that you have not obtained, then know that there will be a fierce war from God and His apostles (Quraish Shihab, 2012). That is the interpretation of M. Quraish Shihab, which in meaning he translates the word al-harb in accordance with the original purpose of war. He even added by giving tendency more meaning to the word, by adding the definition of "terrible" to the word al-harb.

According to him, the word terrible is understood from the form of nakirah (indefinite) in words (حَربُ) harb. It is hard to imagine how fierce the war was, let alone it was fought by God, and it felt too big if the cannon was used to kill flies. Because of this, many understand the power of being meant not in their war, but in this threat. Even if its fierceness in war, it is sourced from His Messenger. Is not the war originated from Allah and His Messenger, as read above? The intended war does not have to be in the form of taking up arms, but all efforts to eradicate and stop the practice of usury. If they use weapons, they, too, can be faced with the power of weapons (Quraish Shihab, 2012).

\section{The Relational Meaning of Al-Harb's Word whose object is Allah and His Messenger}

The last type of relation is the meaning of the word al-harb, namely the word al-harb, whose object is Allah and His Messenger. This also becomes a special verse because this verse is the only verse that uses the word al-harb with shighat fi'il mudhari, namely the word of Allah Almighty: (Q.S Al-Maidah [5]: 33)

The word يُحَارِبُونَ in verse illustrates the meaning of defiance (framed in various forms of disobedience) or resistance by violating all the commands and suggestions of God that are contained in the Qur'an and in the sunnah of the Prophet.

M. Quraish Shihab, in his Al-Misbah interpretation, interprets the word with a similar

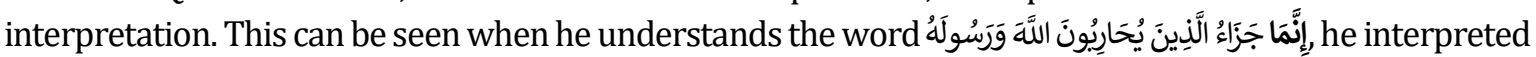
the editorial, namely violating arrogantly with the provisions of the Prophet (Quraish Shihab, 2012). Then he explained the asbab an-nuzul from the verse that the verse came down related to the punishment determined by the Prophet. In the case of the tribe of al-urainiyyin. Imam Bukhari related that a group of people from the 'Ukal and rain Urainah tribes came to meet the Prophet, after declaring their Islam. They complained to the Prophet about their lives. So the Prophet gave a number of camels so they could use them by drinking milk and urinating. In the middle of the road, they killed the camel herder even though they were apostates. Hearing this incident, the Prophet sent a cavalry who had captured them before they arrived in their village. Troops who captured the robbers cut off their hands and feet, gouged their eyes with a heated iron, then held them to death. In another narration, they were thrown into the desert so that they were thirsty without being given a drink to end. This verse goes down to reprimand the treatment. Therefore, the reduction uses the word only in his word: retaliation against them is only, etc. 
IJIK, Vol. 9 No. 2: 61-71

Semantic Study Of Al-Harb Words In The Qur'an According To The Az-Zuhaili Wahbah

Ahmad Ridla Syahida

This verse, as stated above, comes down to the case of al-Urainiyyin, but because the editors are general in nature, of course, in accordance with the interpretation of "the understanding of the text of the verse is not based on its sabab nuzul but based on its general editorial." The scholars discussed the general meaning of the word; in this case, the sentence yuharibuna allah wa rasulahu / fighting against Allah and His Messenger. Now, in this case, the scholars differed;

Imam Malik understood it in the sense of taking up arms to seize the property of other people, which basically had no animosity between those who deprived them of property, both of which took place in cities and in remote locations. Imam Abu Hanifah considered that the seizure had to occur in a remote place so that, if it happened in the city or in a crowded place, he was not included يُحَارِبُونَ .

\section{Interpretation of the words Al-Harb}

As in the discussion of the interpretation of Wahbah Az-Zuhaili on the word al-qital, In this discussion, the writer also tries to present the description of Wahbah Az-Zuhaili about the verses contained in the word Al-Harb, as well as analyzing the various characteristics or characteristics of his interpretation around the word.

In this discussion, the author will try to present all the verses that contain the word al-harb, which amounts to five verses of this verse. The authors do see the verses that talk about the word al-harb not as much as the verses that talk about al-qital; it is also hoped that by presenting all of the verses, it can provide a comprehensive and comprehensive picture of the interpretation of the verses.

To facilitate the analysis of the verses, the authors categorize as follows:

1. Interpretation of Al-Harb Words That Stand Alone.

The first verse that the author presents from the interpretation of Wahbah Az-Zuhaili is, regarding the interpretation of the word al-harb, which stands alone in Q.S Muhammad [47]: 4.

This letter is named after the message of Muhammad; this is because, in the second verse, mention the name (Prophet) of Muhammad. Another name for this letter is surah al-qitāl because it describes the war that is permitted by Allah Almighty and because through the verses, it is explicitly mentioned the word al-qitāl and is taught how to kill the fastest (Quraish Shihab, 2012).

This is understood from the sentence editor (فَضَرْبَ الرَّقابِ), fa dharb ar-riqab, in essence, means to kill in any way. However, it seems that the term was used not only because it is a beautiful figurative word to use, but also because it is a standard method at that time. And more important is because it is the fastest method of killing, and because of its speed, the victim does not suffer too much. Scientifically, it has been proven that the neck is a connective tissue between the head and all organs of the body. So, if the human nerve tissue is managed, all the main functions of the body's organs will weaken. And if the arteries are cut off, the blood stops and cannot feed the brain. Likewise, if the respiratory tract has been lost, humans can no longer breathe. Under these conditions, humans will die quickly (Quraish Shihab, 2012).

Returning to Wahbah Az-Zuhaili's interpretation of the word al-harb contained in verse, he explained that the editor (تَضَعَ الْحَرْبُ أَوَََْرَزَهَ) contains balaghah element, i.e. isti'arah taba'iyyah (Suryaningsih \& Hendrawanto, 2018), wherein the series of words there is a ceasefire likeness (stopping the war) by putting the instrument of war which word (تَضَ) is musytaq (invented word) from the word (وضع) which means putting, but saying (تَضَعَ) in the verse that is finished or stopped. The following author presents the explanation:

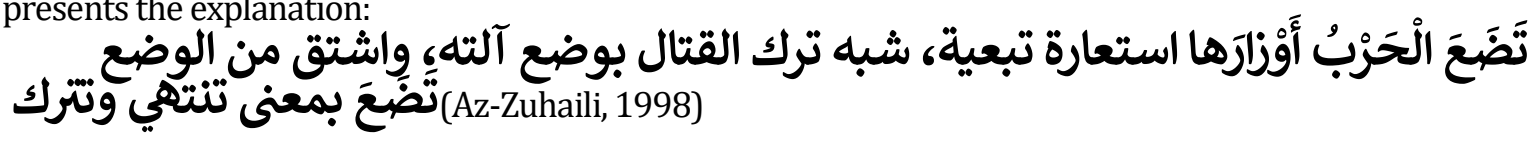


Furthermore, Wahbah Az-Zuhaili explained the word al-harb, when explaining from the aspect of linguistic aspects. That the word series is majaz (metaphor) describes the cessation of war (ceasefire), as for the explanation as follows:

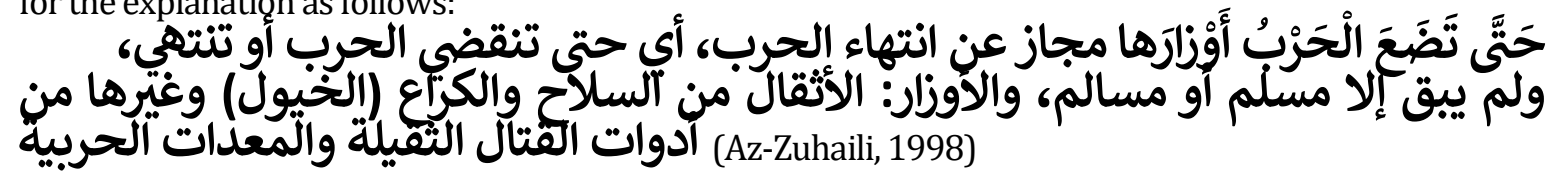

From his explanation, Wahbah Az-Zuhaili interpreted the word al-harb with the meaning of war in accordance with its original meaning.

The second verse about the interpretation of Wahbah Az-Zuhaili on the word al-harb which stands alone (Q.S Al-Maidah [5]: 64)

In this verse, Wahbah Az-Zuhaili interprets the word al-harb in accordance with the original meaning of war; this can be seen from the interpretation of the word (mufradat), as follows:

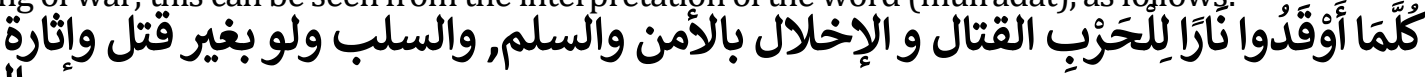
(Az-Zuhaili, 1998)

In terms of word sequences, the series contains elements of balaghah which are the form of isti'arah where the blazing emotions of war are likened to a blazing fire because when viewed war takes life as embers also devour wood to dust. As Wahbah Az-Zuhaili's description of the word follows:

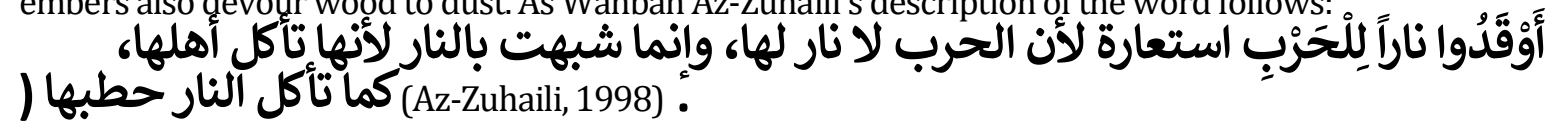

The third verse of this type is the word of Allah in QS Al-Anfal [8]: 57:

In this last verse, Wahbah Az-Zuhaili does not explain in detail from the linguistic aspects of the word al-harb; it is seen that the phrase al-harb in verse is clearly recognized as meaning mostly war.

2. Interpretation of the word Al-Harb whose appeal (invitation to war) comes from Allah and His Messenger

Ayat yang berbicara dalam konteks ini jika dilihat, hanya terdapat pada satu ayat saja, yaitu pada (Q.S Al-Baqarah [2]:279).

Verses that speak in this context, when seen, are only found in one verse, namely in (Q.S. Al-Baqarah [2]: 279).

In accordance with the results of the author's analysis, that the use of the word al-harb in this verse is almost similar to the use of the word al-qital, whose subject is attributed to God. The war on the model of these verses most of the commentators do not understand them intrinsically, but the relational understanding between the various words surrounding the verse.

As what Wahbah Az-Zuhaili did in interpreting the word al-harb in verse. Bahwasannya meant by (بحَرْبِ مِنَ اللَّهِ)war from Allah and His Messenger, as follows:

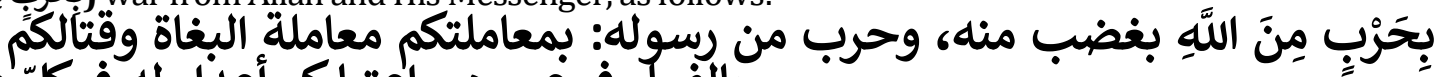

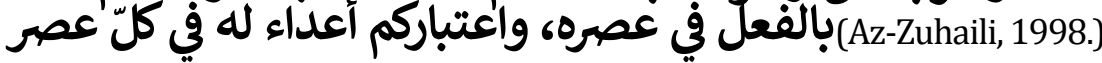

War from Allah is in the form of inflicted anger from him, and war from His Messenger, namely by the treatment (interaction) of criminals and fighting against his time, and making enemies (for every usury eater) in every age.

Wahbah Az-Zuhaili interprets al-harb in verse as (غضب) hatred (wrath) from Allah is not explained in its original meaning. Then when viewed from the aspect of balaghah the word al-harb here uses the 
IJIK, Vol. 9 No. 2: 61-71

Semantic Study Of Al-Harb Words In The Qur'an According To The Az-Zuhaili Wahbah

Ahmad Ridla Syahida

form of nakirah (حرب) this according to Wahbah Az-Zuhaili is a form of scare (التهويل) that is with a very loud war invitation. The understanding of the word is almost the same as what the writer quoted from M. Quraish Shihab's explanation in the previous discussion, although the author sees Wahbah Az-Zuhaili not interpreting the word al-harb according to its original meaning of war is real if you see an explanation of its linguistic aspects.

But in terms of understanding the aspects of balaghah, it is almost the same as M. Quraish Shihab wherein the meaning he translates the word الْحَبْ in accordance with the original purpose of war, he even added by giving a tendency to the meaning of the word more by adding the meaning of "terrible" to the word al-harb .

Furthermore, according to him, the word terrible is understood from the form of nakirah (indefinite) in the word حَرْبُ harb. It is hard to imagine how fierce the war was, let alone it was fought by God, and it felt too big if the cannon was used to kill flies. Because of this, many understand the power of being meant not in their war, but in this threat. Even if its fierceness in war, it is sourced from His Messenger. Is not the war originated from Allah and His Messenger, as read above? The intended war does not have to be in the form of taking up arms, but all efforts to eradicate and stop the practice of usury. If they use weapons, they, too, can be faced with the power of weapons (Quraish Shihab, 2012).

3. Interpretation of the word Al-Harb whose object is Allah and His Messenger

As the author said in the previous discussion, that the words al-harb whose objective is Allah and His Messenger, are the only verses that use the word al-harb with shighat fi'il mudhari, namely the word of Allah Almighty: (QS Al-Maidah [5]: 33)

In terms of language (المفردات اللغوية) Wahbah Az-Zuhaili does not interpret the word al-harb in accordance with its original meaning, this can be seen from the explanation of the word as follows:

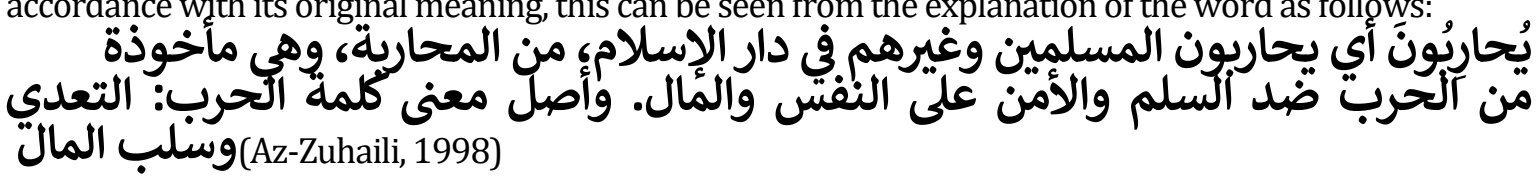

Yuharibuna, namely fighting the Muslims and others who are in the Islamic territory, the word is taken from the word (الححاربة) which originates from the word (الحرب) which means the opposite of peace and peace of soul and property, while the original meaning of the word al-harb is wrongdoing and seizing other people's property unnaturally.

From his explanation, he understands that the word al-harb there is a form of majaz (metaphor) that is relational, the word indicates to other meanings that fit the context of the verse, Wahbah Az-Zuhaili views that the word al-harb is juxtaposed with the object of God and His messenger, their balaghah is majaz in the form of idhafah mudhaf (words that rely on) on a series of sentences that are discarded. If it is destined, the original set of sentences is, (يحاربون عباد الله), fighting the servants of God. According to him, the reason he was destined like that because if it was not destined, in reality, God could not be fought (essentially) nor could he be defeated. The author includeș an explanation of the context as follows:

\section{يُحارِبِونَ اللَّة مجاز على حذف مضاف أي يحاربون عباد اللَ لأن الله لا يحارب ولا} يغالب(Az-Zuhaili, 1998)

If it is seen that Wahbah Az-Zuhaili interprets the series of verses with the subsequent set of verses, verse 34 into one theme group by giving the title (حد الحرابة أو حكم قطاع الطرق), sanctions for robbers and robbery (thief). From giving the theme of the verse group by Wahbah Az-Zuhaili, it can be understood that the word al-harb in verse is not interpreted according to its original meaning but is interpreted outside its original meaning. This is confirmed by an explanation of its interpretation as follows: 


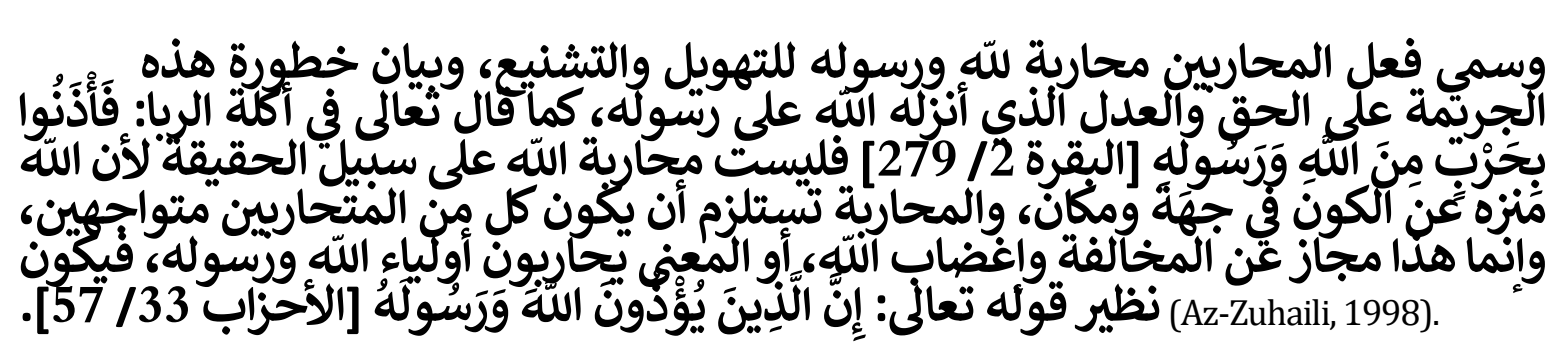

He has named robbing by fighting God and His Messenger, as a form of reproach and invective. Also, as an explanation of the dangers of these crimes that can damage the justice and truth that has been revealed by Allah to His Messenger. The verse is similar to the word of Allah Almighty revealed to usurers, so know that Allah and His Messenger will fight you (Q.S Al-Baqarah [2]: 279). Then not what is meant by fighting Allah is understood in essence because Allah Most High from his existence occupies a place and direction. Whereas the so-called war must be countered by the presence of both sides facing each other, while in this sentence it is nothing but a form of majaz which describes the resistance and hatred of God, or it can be interpreted as mostly fighting the guardians (servants) of Allah and His Messenger, then the editor is similar to the word of Allah ta'ala in surah al-ahzab verse 57, Verily those who hurt Allah and His Messenger.

\section{CONCLUSION}

From the results of a comprehensive analysis of the objects studied in this study, namely the semantic study of the word al-harb in the Qur'an according to the interpretation of Wahbah Az-Zuhaili in the understanding of Al-Munir, the author will try to conclude several points as follows:

Viewed from the perspective of the knowledge of wahbah az-zuhaili trying to combine the interpretation of bil ma'tsur and the interpretation of bil ma'qul (ar-ra'yi), with the language style and contemporary approach Wahbah Az-Zuhaili works to present a solution which is solutive and in accordance with the conditions of the times. bil ma'tsur with a history that relies on the sunnah nabawiyah and the opinion of the salaf cleric, bil ma'qul is rational ijtihad that adheres strictly to scientific principles that are well known in the Islamic world. The interpretation method used by Wahbah Az-Zuhaili in AlMunir's interpretation tends to take a modern pattern, namely the tahlilî (deductive-analytical) method and to apply a semi-thematic method. As meant by the technique of tahlilî a method of interpretation that intends to explain the verses of the Qur'an from all its aspects the steps taken in this interpretation are also arranged in the order of the Mushhaf; by explaining the elements related to everything contained in verse, such as linguistic aspects including i'rab, balaghah, vocabulary meanings; the historicity of the verse (asbâb al-nuzûl) and the Munâsabat (correlation) of a verse with the previous verse. The interpretation style Apart from the form of jurisprudence, this interpretation is also thick with the nuances of literature, culture, and society (al-âdâb al-ijtimâ ').

\section{REFERENCES}

Al-Ja'wani, M. I. N. I. 'Abdurrahman. (1983). Al-Qitāl Fī Al-Islām Ahkāmuhu Wa Tasyrī'ātuhu (2nd Ed.). Riyad: Maktabah Madinah.

Az-Zarqāni, M. A. A.-A. (2010). Manāhil Al-'Irfān Fī 'Ulūm Al-Qur'ān (3rd Ed.). Cairo: Dar As-Salam.

Az-Zuhaili, W. (1998). At-Tafsîr Al-Munîr Fi Al-'Aqîdah Wa Asy-Syarî’ah Wa Al-Manhaj. Damaskus: Dar Al-Fikr.

Fâris, A. Al-H. A. I., \& Faris, I. Z. I. (2013). Mu'jam Maqayis Al-Lughah. Turath For Solutions. 
Hanafi, M. M. (2013). Moderasi Islam: Menangkal Radikalisasi Berbasis Agama. Jakarta: Ikatan Alumni Al-Azhar Mesir Cabang-Indonesia.

Junaidy, A. B. (2018). Perang Yang Benar Dalam Islam. Al-Daulah: Jurnal Hukum Dan Perundangan Islam, 8(02), 486-512.

Makhmudah, S. (2015). Dinamika Dan Tantangan Masyarakat Islam Di Era Modernisasi. Jurnal Lentera: Kajian Keagamaan, Keilmuan Dan Teknologi, 1(2), 242-259.

Quraish Shihab, M. (2012). Tafsir Al-Mishbah. In Jakarta: Lentera Hati (5th Ed.). Jakarta: Lentera Hati.

Rodin, D. (2016). Islam Dan Radikalisme: Telaah Atas Ayat-Ayat "Kekerasan" Dalam Al-Qur'an. Addin, 10(1), 29-60.

Sariningsih, W., Yuniyanto, T., \& Isawati, I. (2019). Perang Khandaq (Tahun 627 M): Studi Tentang Nilai-Nilai Kepemimpinan Dan Relevansinya Dengan Materi Sejarah Islam. Jurnal Candi, 19(1), 125-137.

Shihab, M. Q. (1996). Wawasan Al-Quran: Tafsir Tematik Atas Pelbagai Persoalan Umat. Mizan Pustaka.

Sugiyono, P. (2011). Metodologi Penelitian Kuantitatif Kualitatif Dan R\&D. Alpabeta, Bandung.

Suryaningsih, I., \& Hendrawanto, H. (2018). Ilmu Balaghah: Tasybih Dalam Manuskrip "Syarh Fī Bayān Al-Majāz Wa Al-Tasybīh Wa Al-Kināyah." Jurnal Al-Azhar Indonesia Seri Humaniora, $4(1), 1-10$.

Wartini, A. (2014). Corak Penafsiran M. Quraish Shihab Dalam Tafsir Al-Misbah. Hunafa: Jurnal Studia Islamika, 11(1), 109-126. 